\title{
Interactions of Microplastics with Freshwater Biota
}

\author{
Christian Scherer, Annkatrin Weber, Scott Lambert, and Martin Wagner
}

\begin{abstract}
The ubiquitous detection of microplastics in aquatic ecosystems promotes the concern for adverse impacts on freshwater ecosystems. The wide variety of material types, sizes, shapes, and physicochemical properties renders interactions with biota via multiple pathways probable.

So far, our knowledge about the uptake and biological effects of microplastics comes from laboratory studies, applying simplified exposure regimes (e.g., one polymer and size, spherical shape, high concentrations) often with limited environmental relevance. However, the available data illustrates species- and materialrelated interactions and highlights that microplastics represent a multifaceted stressor. Particle-related toxicities will be driven by polymer type, size, and shape. Chemical toxicity is driven by the adsorption-desorption kinetics of additives and pollutants. In addition, microbial colonization, the formation of heteroaggregates, and the evolutionary adaptations of the biological receptor further increase the complexity of microplastics as stressors. Therefore, the aim of this chapter is to synthesize and critically revisit these aspects based on the state of the science in freshwater research. Where unavailable we supplement this with data on marine biota. This provides an insight into the direction of future research.

In this regard, the challenge is to understand the complex interactions of biota and plastic materials and to identify the toxicologically most relevant characteristics of the plethora of microplastics. Importantly, as the direct biological impacts of
\end{abstract}

This chapter has been externally peer reviewed.

C. Scherer $(\bowtie)$, A. Weber, and S. Lambert

Department Aquatic Ecotoxicology, Goethe University, Max-von-Laue-Str. 13, 60438

Frankfurt am Main, Germany

e-mail: c.scherer@bio.uni-frankfurt.de

M. Wagner

Department of Biology, Norwegian University of Science and Technology (NTNU),

Trondheim, Norway 
natural particles may be similar, future research needs to benchmark synthetic against natural materials. Finally, given the scale of the research question, we need a multidisciplinary approach to understand the role of microplastics in a multiple-particle world.

Keywords Autecology, Feeding types, Microplastic-biota interaction, Polymers, Suspended solids, Vector

\section{Introduction}

Over the past decade, microplastics (MPs) have become a prominent environmental concern, mainly because of their frequent and ubiquitous detection in marine and freshwater ecosystems. Therefore, biota will likely encounter and interact with MPs. In addition, MPs are a heterogeneous class of pollutants with a broad range of individual properties such as material type, particle size, and particle shape. These diverse material characteristics make them potentially available to a broad range of neustonic (buoyant materials, density $<1 \mathrm{~g} \mathrm{~cm}^{-3}$ ), pelagic (materials in suspension), and benthic species (sedimenting materials, density $>1 \mathrm{~g} \mathrm{~cm}^{-3}$ ). This enables MPs to penetrate aquatic food webs at multiple trophic levels and ecological niches.

To date, research into MP exposure for freshwater biota is limited. Yet, marine research has shown malnutrition caused by the intensive feeding on MPs replacing parts of the natural diet [1-3]. Additionally, further ingestion-related effects include blockages and injuries to the digestive tract [4], inflammatory response [5], and desorption of xenobiotics [6]. Obviously, all of these responses presuppose feeding and ingestion of MPs. As such, the aim of this chapter is to discuss the diverse interactions between MPs and biota that may occur in the environment. In the first section, we focus on factors influencing the ingestion of MPs considering the impact of the different physical properties of MPs and feeding types of freshwater species. In the second section, we provide an overview and analysis of the observed MP effects in terms of their physical, chemical, and vector-related impacts. This is followed by a comparison of the similarities in the effects caused by exposure to naturally occurring particles and MPs. Finally, we conclude by discussing the wider implications of MPs toward freshwater systems.

\section{Factors Influencing Microplastic Ingestion by Freshwater Biota}

Species in freshwater ecosystems are part of complex food webs and forage on a wide diversity of food types, utilizing a variety of different feeding strategies. Notwithstanding this diversity, the classification by feeding types or by food types is commonly used to group biota. For instance, suspension feeders obtain nutrients from particles suspended in water, deposit feeders forage for particles in 
sediments, fluid feeders feed on other biotas fluids, and suction feeders ingest the prey together with the surrounding water. The utilized morphological structures determine further classifications. For example, filter feeders (e.g., daphnids) use specialized filtering structures to strain suspended particles, and raptorial feeders (e.g., copepods) actively capture and process suspended particles by modified appendages. Further typically used classifications are collectors (e.g., chironomids), shredders (e.g., amphipods), scrapers (e.g., gastropods), and predators (e.g., odonates) [7]. Another way to categorize species is based on their diet. For instance, bacterivores feed on bacteria, herbivores feed on plants, carnivores feed on animals (e.g., zooplanktivores, insectivores), and detritivores feed on decomposing materials. These groupings imply clear boundaries, although some species feed on multiple food sources (e.g., generalist, omnivorous) or have the ability to switch between food sources (opportunistic feeders).

Primary producers like unicellular algae or bacteria as well as particulate organic matter (POM) provide nutrients for a broad range of pelagic and benthic species. Thus, small MPs are in a similar size range to the natural food of these consumers. To understand the capacities of different species to feed on specific size classes, limnologists have frequently used polymer beads as tracers [8-10]. Although these studies primarily focus on pelagic zooplankton communities, they illustrate that the intake of food and MPs depend on complex interactions between biotic (e.g., feeding type, physiological state, competition, food size, and availability) and abiotic factors (e.g., temperature). Accordingly, they provide a useful starting point to discuss MP ingestion and effects.

\subsection{The Role of Feeding Types}

\subsubsection{Invertebrates}

Suspension and filter feeders like protozoans, rotifers, cladocerans, and mussels are assumed to be especially prone to MP ingestion because they commonly feed on suspended particulate matter (SPM) and ingest a variety of seston components. The ingestion of MPs by these feeding types has been shown in numerous studies (Table 1). For instance, bacterivorous and herbivorous ciliates (e.g., Halteria sp.), flagellates (e.g., Vorticella sp.), rotifers (e.g., Anuraeopsis fissa), and cladocerans (Daphnia sp.) can feed readily on plastic beads [9, 10]. While data on MP ingestion by pelagic filter-feeding zooplankton is relatively abundant, one prominent group of filter feeders, the bivalves, is underrepresented. Bivalves are known to feed effectively on SPM, including MP, which is ingested by marine mussels (e.g., Mytilus edulis, [24]) and freshwater clams (Sphaerium corneum, 1-10 $\mu \mathrm{m}$ polystyrene (PS) beads; Anodonta cygnea, 5-90 $\mu \mathrm{m}$ polystyrene (PS) beads and fragments; unpublished data).

In addition to organisms specialized in feeding on SPM, a variety of organisms forage for particles in sediments. Although MP exposure may be as relevant for deposit feeders (feeding on fine particulate matter and associated biota in sediments) as for filter feeders, only a few studies have investigated the ingestion of MPs for this mode of feeding. The blackworm Lumbriculus variegatus and the 
Table 1 Summary of the results of uptake studies with microplastic particles and freshwater species

\begin{tabular}{|c|c|}
\hline Uptake $\left(\mathrm{P}\right.$ Ind $\left.^{-1} \mathrm{~h}^{-1}\right)$ & Species \\
\hline \multicolumn{2}{|l|}{ Ciliates } \\
\hline Yes $(13.6-1,200)$ & 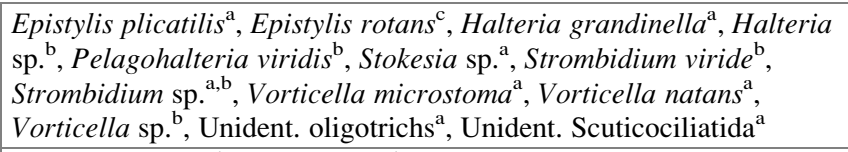 \\
\hline No & 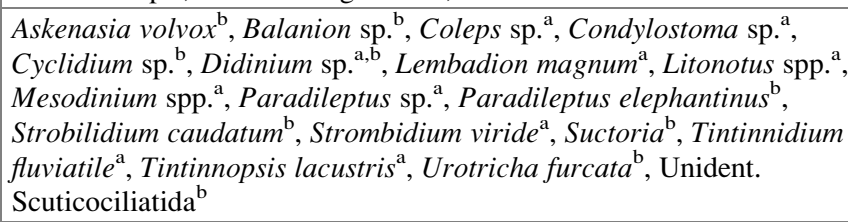 \\
\hline
\end{tabular}

Flagellates

\begin{tabular}{|c|c|}
\hline Yes (2.6-103) & 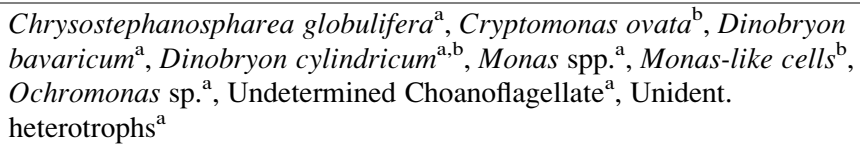 \\
\hline No & 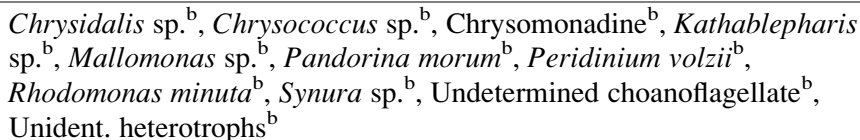 \\
\hline
\end{tabular}

Rotifera

\begin{tabular}{l|l}
\hline Yes $(2.5-3,200)$ & Anuraeopsis fissa ${ }^{\mathrm{a}, \mathrm{d}, \mathrm{e}}$, Brachionus angularis $^{\mathrm{e}}$, Brachionus calyciflorus $^{\mathrm{f}}$,
\end{tabular} Brachionus koreanus $^{\mathrm{s}}$, Conochilus unicornis ${ }^{\mathrm{b}, \mathrm{d}, \mathrm{e}}$, Conochilus sp. ${ }^{\mathrm{a}}$, Filinia longiseta $^{\mathrm{a}, \mathrm{d}, \mathrm{e}}$, Filinia terminalis $^{\mathrm{f}+}$, Gastropus sp. ${ }^{\mathrm{a}}$, Hexarthra mira $^{\mathrm{b}}$, Hexarthra sp. $^{\mathrm{a}}$, , Kellicottia bostoniensi ${ }^{\mathrm{a}}{ }$, Keratella cochlearis $^{\mathrm{d}, \mathrm{e}}$, Keratella cochlearis tecta ${ }^{\mathrm{d}}$, Keratella quadrata ${ }^{\mathrm{e}}$, Keratella $_{\text {spp. }}{ }^{\mathrm{a}}$, Lecane

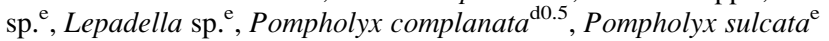

\begin{tabular}{l|l}
\hline No & Anuraeopsis fissa $^{\mathrm{d}}{ }^{6}$, Ascomorpha saltans $^{\mathrm{e}}$, Asplanchna priodontata $^{\mathrm{b}}$,
\end{tabular}
Asplanchna sp. $^{\mathrm{e}}$, Collotheca spp. $^{\mathrm{e}}$, Conochilus unicornis ${ }^{\mathrm{d} 6}$, Filinia longiseta $^{\mathrm{d} 6}{ }$, Filinia terminalis ${ }^{\mathrm{b}, \mathrm{f}}$, Kellicottia longispina $^{\mathrm{b}}$, Keratella $^{\circ}$ cochlearis $^{\mathrm{d} 6}$, Keratella cochlearis tecta ${ }^{\mathrm{d} 6}$, Keratella quadrata $^{\mathrm{d}}$, Polyarthra spp. ${ }^{\mathrm{a}, \mathrm{b}, \mathrm{e}}$, Pompholyx complanata ${ }^{\mathrm{d} 3-6}$, Synchaeta spp. $^{\mathrm{b}, \mathrm{e}}$, Trichocerca pusilla ${ }^{\mathrm{e}}$, Trichocerca spp. ${ }^{\mathrm{a}}$

\begin{tabular}{|c|c|}
\hline Annelida & \\
\hline Yes $(0-1)$ & Lumbriculus variegatus ${ }^{\mathrm{h}, \mathrm{i}}$ \\
\hline No & - \\
\hline \multicolumn{2}{|l|}{ Crustacea } \\
\hline Yes $(1-28,000)$ & 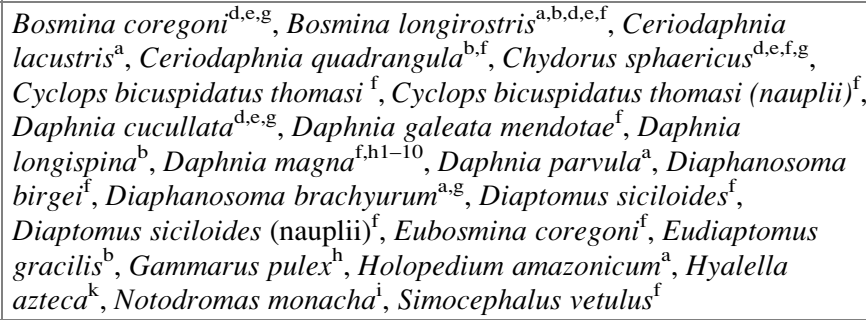 \\
\hline No & 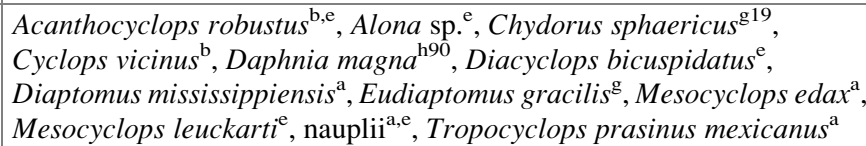 \\
\hline
\end{tabular}


Table 1 (continued)

\begin{tabular}{|c|c|}
\hline Uptake $\left(\mathrm{P}\right.$ Ind $\left.^{-1} \mathrm{~h}^{-1}\right)$ & Species \\
\hline \multicolumn{2}{|l|}{ Insecta } \\
\hline Yes $(0.05-15.6)$ & Chironomus riparius $^{\mathrm{h}}$ \\
\hline No & - \\
\hline \multicolumn{2}{|l|}{ Mollusca } \\
\hline Yes $(0.16-104)$ & $\begin{array}{l}\text { Anodonta cygnea }{ }^{\mathrm{w}}, \text { Physella } \text { acuta }^{\mathrm{h}}, \text { Potamopyrgus antipodarum }^{\mathrm{I}} \text {, } \\
\text { Sphaerium corneum }^{\mathrm{u} 1-10}\end{array}$ \\
\hline No & Sphaerium corneum ${ }^{\mathrm{u} 90}$ \\
\hline \multicolumn{2}{|l|}{ Pisces } \\
\hline Yes & 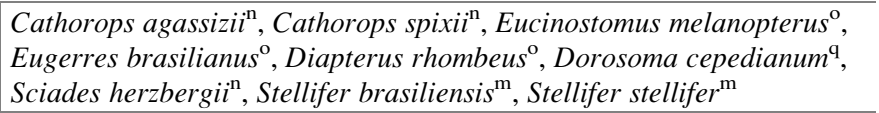 \\
\hline No & - \\
\hline \multicolumn{2}{|c|}{ 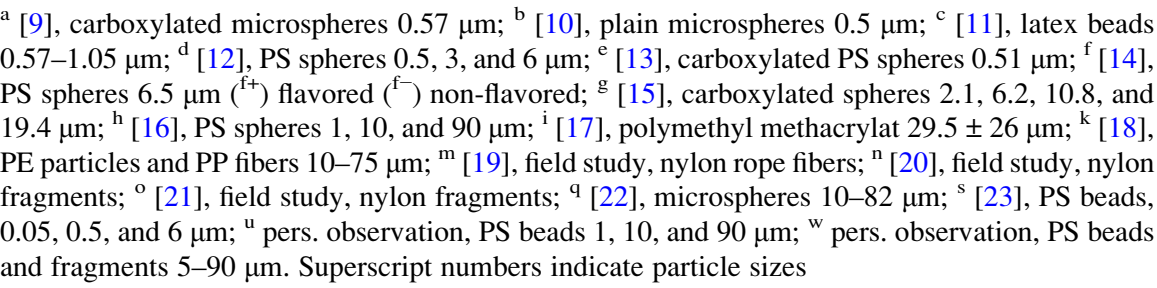 } \\
\hline
\end{tabular}

aquatic larvae of Chironomus riparius ingest a broad size range of MPs implying a relative nonselective feeding on sediment components (Table 1 [16]). Surfacegrazing gastropods Physella acuta and Potamopyrgus antipodarum as well as the shredder Gammarus pulex have also been shown to ingest MPs through water-/sediment-borne ( $P$. acuta and $G$. pulex [16]) and food-associated (P. antipodarum and G. pulex [17]) exposure routes. It is unknown if these results are relevant for other benthic deposit feeders considering the diverse ecological niches and feeding types (e.g., collector-gatherer, filter-gatherer, shredders, scrapers).

An analysis of studies on MP ingestion by freshwater species indicates that their general role in the food web (generalist vs. specialized feeders) may determine dietary MP uptake. Generalists (e.g., Daphnia sp.) or deposit feeders like the dipteran $C$. riparius frequently ingested MPs in laboratory experiments, while this is not the case for more specialized raptorial and carnivorous feeders like the cyclopoid copepod Mesocyclops sp., the rotifer Asplanchna sp. as well as the ciliate Didinium sp. (Table 1). However, given the potential of MPs to enter complex aquatic food webs at low trophic levels, an indirect ingestion via the prey is also likely for carnivorous predators. For instance, the transfer of MPs via prey was observed in food chain experiments with D. magna and Chaoborus flavicans (personal observation). While the predator $C$. flavicans did not directly ingest suspended MPs (PS beads, $10 \mu \mathrm{m}$ ), the feeding of MP-containing daphnids (pre-fed on MPs) resulted in an indirect uptake of $10 \mu \mathrm{m}$ MPs. 
Besides these general trends, available studies illustrate that species of the same functional feeding type have species-specific and sometimes highly divergent MP feeding rates. For instance, the filter-feeding cladocerans Daphnia longispina and Ceriodaphnia quadrangula ingested $230 \times 10^{3} \mathrm{P} \mathrm{I}^{-1} \mathrm{~h}^{-1}$ and $176 \times 10^{3} \mathrm{P} \mathrm{I}^{-1} \mathrm{~h}^{-1}$, respectively. In comparison, rotifers (e.g., Hexarthra mira, $38.1 \times 10^{3} \mathrm{P} \mathrm{I}^{-1} \mathrm{~h}^{-1}$ ) and ciliates (e.g., Halteria sp., $46.8 \mathrm{P} \mathrm{I}^{-1} \mathrm{~h}^{-1}$ ) ingest MPs at a much slower rate [10]. While differences are mainly caused by the species' morphology and autecology, numerous other factors (e.g., appetite, MP type and concentration, quantification methods) may also contribute. Overall, the most commonly studied invertebrate species are zooplankton. However, we still know little about the interactions of MPs with other prominent invertebrate freshwater taxa, e.g., Annelida, Insecta, Decapoda, and Mollusca.

\subsubsection{Vertebrates}

When considering vertebrate species, MP uptake is documented in laboratory and field studies for several fish species (Table 1). In contrast, no information is available for amphibians. Considering the diversity of vertebrates acting as predators, herbivores, detritivores, or omnivores, we can assume that many species, at least in principle, have the capacity to ingest MPs depending on their feeding strategies. However, predicting MP ingestion by vertebrates solely based on feeding types may be too short sighted. For instance, grouping fishes into specific guilds/feeding groups is an imprecise and difficult task. Indeed, typical terms like detritivores, herbivores, and carnivores as well as generalist, specialist, and opportunist are used, but the variability of feeding (e.g., during development) and the trophic adaptability (ability to switch food sources) impede a precise classification [25]. The ingestion of prey through suction feeding is utilized by the majority of teleosts, which allows this high flexibility to exploit a variety of food sources [26]. Thus, accidental (mistake MPs for prey) and indirect ingestion of MPs (via prey containing MPs) are probable. The documented MPs in several fishes collected in the field (e.g., catfish, perch, drum, Table 1) support this assumption.

\subsection{The Role of Particle Size, Shape, and Taste}

\subsubsection{Size and Shape}

The importance of particle size in the acquisition of particulate food has been studied for pelagic protozoans, rotifers, and crustaceans (e.g., [26, 27]). For filterfeeding taxa, a distinct relation between morphology and particle size has been observed. Here, the minimum ingested particle size is mainly determined by the mesh size of the filtering apparatus. The maximum size is determined by the morphology of mouthparts and, in the case of cladocerans, the opening width of the carapace. Additionally, Burns [8] and Fenchel [27] describe a correlation 
A

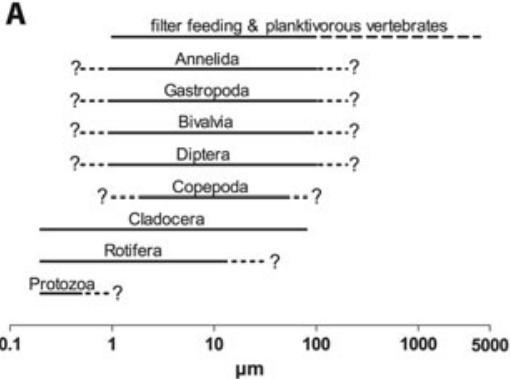

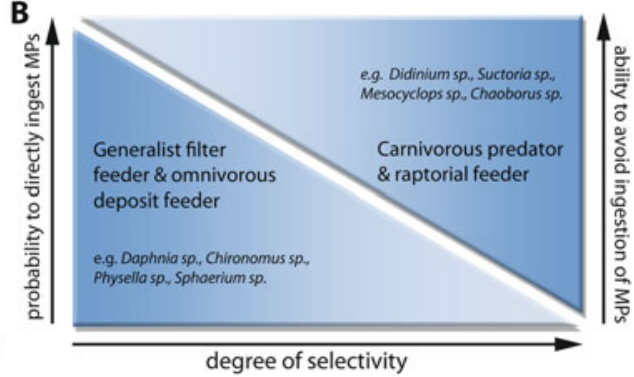

Fig. 1 Estimated feeding size ranges on microplastic particles (a). Dotted lines and question marks indicate the lack of min to max limits based on ingested size classes. An increasing feeding selectivity decreases the probability to directly ingest microplastics (b)

between the maximum ingestible particle size and the overall size of several cladoceran and protozoan species. Studies with the aquatic larvae of the dipteran $C$. riparius confirm this pattern for a benthic deposit feeder. Here, only individuals with a head capsule width larger than $400 \mu \mathrm{m}$ ingested $90 \mu \mathrm{m}$ PS spheres ([16], Table 1).

Fine-mesh filter feeders (size range $0.2-75 \mu \mathrm{m}$; e.g., Daphnia magna) are highly efficient bacteria feeders, whereas coarse mesh filter feeders (macrofiltrators, size range $>2 \mu \mathrm{m}$; e.g., Holopedium gibberum) feed mainly on larger particles [28]. Results from feeding studies with polymer spheres illustrate that several protozoans feed effectively on $0.5 \mu \mathrm{m}$ particles [9]; several rotifers on $0.5,3$, and $6 \mu \mathrm{m}$ particles [19]; and cladocerans on $0.5,3,6,10$, and $20 \mu \mathrm{m}$ particles ([13], Table 1). In comparison, calanoid copepods are macrofiltrators and ingest particles $>2.1 \mu \mathrm{m}$ but not $0.5 \mu \mathrm{m}$ particles (e.g., [10], Fig. 1a). In addition, some species with a broad feeding size range have been shown to selectively forage on specific sizes when exposed to multiple size fractions. For instance, Bosmina sp. ingested large algae cells (Cosmarium sp.) six times faster than a small algae species (Chlorella sp.) [29, 30]. Furthermore, Agasild and Nõges [12] observed higher filtering rates of Daphnia cucullata on 3 and $6 \mu \mathrm{m}$ compared to $0.5 \mu \mathrm{m}$ MPs, whereas the rotifer Conochilus unicornis exhibited an increased filtering rate on $3 \mu \mathrm{m}$ compared to $0.5 \mu \mathrm{m}$ MPs.

Particle shape is another important property determining MP-biota interactions. Currently, the majority of the available literature focuses on MP beads, and it remains unclear whether the investigated species have similar feeding rates on non-spherical MPs (e.g., fibers, fragments). Some species (e.g., G. pulex, D. magna, Notodromas monacha) feed readily on secondary, irregularly shaped MPs [17, 31] with different toxicological profiles (see Sect. 3.1). As most of the MPs found in aquatic ecosystems are not spherical, more research is needed on irregularly shaped MPs. 


\subsubsection{Taste Discrimination}

Many species are able to identify particles with nutritional value. For example, some bacterivorous and herbivorous protozoan, rotifer, and copepod species do not ingest polymer particles in their preferred size ranges (Table 1). Studies with fluorescently labeled bacteria have shown that some ciliates (estuarine oligotrichs) and flagellates prefer bacteria over MPs, while other species (estuarine scuticociliates; e.g., Uronema narina) cannot discriminate between bacteria and MPs [32].

The essential role of "taste" in the feeding of zooplankton [14, 32, 33] was acknowledged when discussing the comparability of feeding studies with synthetic microspheres and labeled bacteria or algae [9, 10, 15]. In rotifers, Bosmina (cladoceran), and copepods (calanoid and cyclopoid), DeMott [14] observed significant differences between feeding rates on flavored and non-flavored polymer particles. While Bosmina and the rotifer Filinia terminalis preferred algal-flavored spheres over untreated ones, D. magna and Brachionus calyciflorus did not [14]. This degree of selectivity was even higher in feeding trials with copepods. Here, calanoid (e.g., Diaptomus siciloides) and cyclopoid (e.g., Cyclops bicuspidatus thomasi) species strongly avoided untreated polymer spheres [14].

Despite the abundance of studies that illustrate pelagic zooplankton feeding on MPs, information about benthic invertebrates and vertebrates in general is scarce. Although drawing conclusions for unexamined species is highly speculative, knowledge on zooplankton can be used as a template to a certain extent. The examined species cover a broad spectrum in terms of their autecology (feeding types, selectivity, and food preferences). The same is true for the unexamined species, which inhabit similar niches and have equally diverse autecologies. Therefore, we hypothesize a similar pattern regarding species-specific size and taste discrimination: Some species will directly feed on available MPs in the size range of their food, while more selective feeders will avoid MP ingestion.

\subsection{Conclusion}

Primary consumers featuring bacterivorous, herbivorous, detritivorous, and deposit-feeding species are commonly specialized in foraging on particulate matter and have the capacity to ingest MP particles. The direct ingestion of MPs might be the major route for primary (e.g., herbivores) and secondary consumers (e.g., zooplanktivores), while apex predators are additionally prone to an indirect ingestion of MPs via prey (food web). The limited literature suggests that generalist and nonselective filter feeders (e.g., daphnids) have higher feeding rates compared to raptorial (e.g., copepods) and deposit feeders. Although studies on benthic invertebrates are scarce, species with detritivorous and omnivorous feeding types (e.g., Annelida, Insecta, Decapoda) may have the potential for ingesting MPs. 
However, the feeding type is not a reliable predictor of MP ingestion as several studies on pelagic zooplankton communities highlight a far more complex MP-biota interaction than currently understood.

Overall, the feeding on particulate matter is a sequential process involving the encounter, pursuit, capture, and ingestion of potential prey [30]. Every single stage is determined by species-specific abilities and preferences to distinguish between favored and non-favored food sources (e.g., size, shape, taste, motile, sessile). Additionally, many taxa can adapt their feeding habits (e.g., targeting a preferred size class and/or nutritional value) in response to environmental conditions (optimal foraging). In general, it appears that the capability to directly ingest MPs decreases with an increasing selectivity in feeding (Fig. 1b). Generalist filter feeders will actively and directly ingest MPs from the water column or sediments in the size range of their typical food, whereas more specialized feeders (e.g., fluid feeders, raptorial carnivorous feeders) will indirectly ingest MPs associated with their prey.

The variety of feeding types and degrees of selective feeding present in aquatic fauna complicates generalizing patterns of MP uptake. This is especially true when comparing experimental to the real exposure scenarios. In the laboratory, virgin spherical microbeads are used, whereas in the environment, irregularly shaped MPs are colonized by microbes (see Sect. 3.2), adsorb extracellular proteins (biofilm), and form hetero-aggregates (increasing size). While MP-biota interactions are hard to predict based on the currently available data, feeding selectivity may be a driving factor (see Fig. 1b for a conceptual model).

\section{Effects on Freshwater Biota}

Studies on the potential adverse effects caused by MP exposures are scarce for freshwater compared to marine species. The few available studies (Table 2) include the filter feeder D. magna [34, 35, 41], the amphipods Hyalella azteca [18] and $G$. pulex [31], the freshwater snail $P$. antipodarum [38] as well as several fishes [37-39]. In this section, the outcomes of these studies are discussed.

\subsection{Physical Impacts}

The evaluation of feeding types (Sect. 2.1) suggests that nonselective filter feeders are especially prone to MP exposures. Based on their high rates of MP filtration and ingestion in laboratory studies, adverse effects induced by the particle toxicity may include blockages, reduced dietary intake, and internal injuries. 


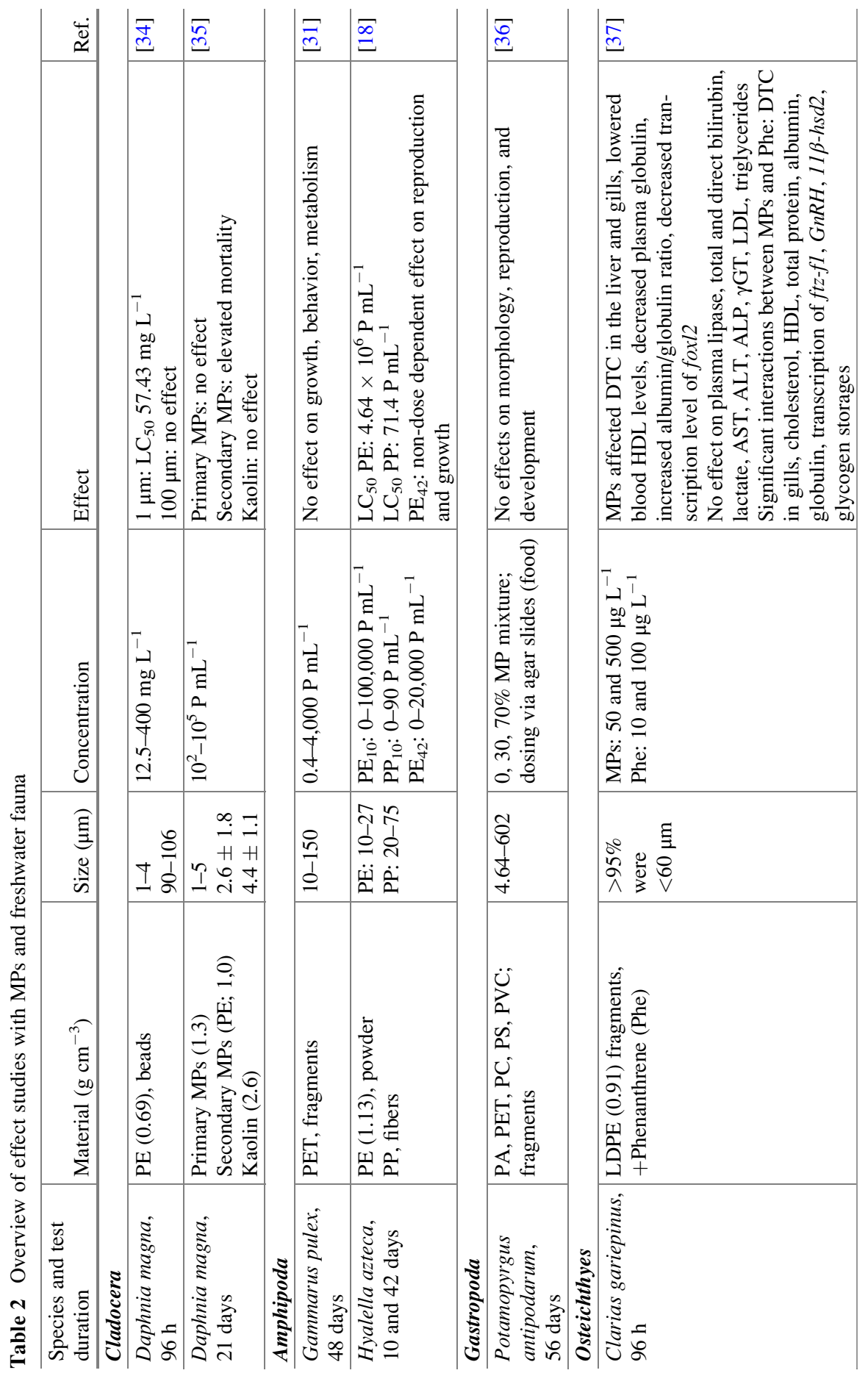




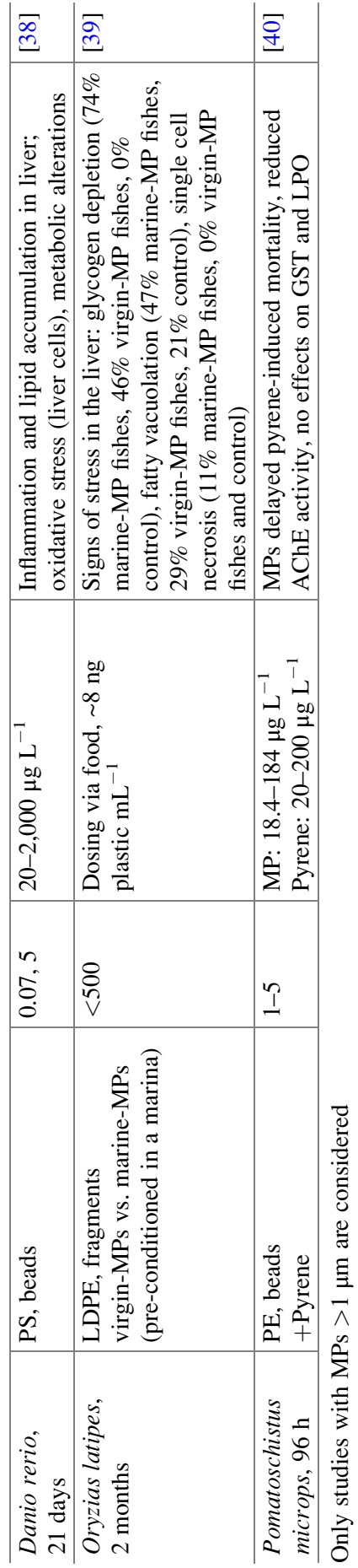




\subsubsection{Algae}

So far, the majority of studies focused on the effects of MPs on consumers of aquatic food webs, and information on primary producers is limited. However, there are some indications that MPs adversely affect algae in a concentration and size-dependent manner [41-43]. For instance, $1 \mu \mathrm{m}$ PVC fragments inhibited the growth and negatively affected photosynthesis $\left(50 \mathrm{mg} \mathrm{L}^{-1}\right)$ of the marine algae Skeletonema costatum [43], while $1 \mathrm{~mm}$ PVC fragments did not induce such alterations. The underlying mechanisms are still unknown, whereby the direct interaction between MPs and algae and formation of aggregates seem to be strongly related. Since algae are used as a food source in ecotoxicological experiments, MPs may induce direct and indirect (quality and quantity of the algae) effects in the consumer.

\subsubsection{Daphnia magna}

In contrast to marine studies, only one filter-feeding freshwater species, D. magna, has been tested thoroughly in chronic and acute exposure regimes. Acute toxicity testing over $96 \mathrm{~h}$ resulted in an elevated immobilization at extremely high concentrations of $1 \mu \mathrm{m}$ polyethylene (PE) particles [34]. With a median lethal concentration $\left(\mathrm{LC}_{50}\right)$ of $75.3 \mathrm{mg} \mathrm{L} \mathrm{L}^{-1}$, these acute effects are (presumably) not environmentally relevant. Compared to this, chronic exposure to nanoscale PS over 21 days $\left(0.22-150 \mathrm{mg} \mathrm{L}^{-1}\right.$, [41]) was not lethal. However, high concentrations of nano-PS (>30 $\mathrm{mg} \mathrm{L}^{-1}$ ) induced neonatal malformations and slightly decreased the reproductive output. Interestingly, the mortality as well as the amount of malformations increased when the daphnids were fed with nano-PS incubated algae (5 days). Since nano-PS particles might be too small for a direct ingestion, the formation of particle-algae aggregates may have resulted in a higher exposure. Furthermore, nano-PS reduced the growth and the chlorophyll a content of algae (Scenedesmus obliquus) indicating a reduced nutritional value of algae cultured with polymer particles.

Ogonowski et al. [35] conducted life-history experiments with D. magna exposed to primary MPs (spherical beads, $1.3 \mathrm{~g} \mathrm{~cm}^{-3}, 4.1 \mu \mathrm{m}$ ), secondary MPs (PE fragments, $\left.1.0 \mathrm{~g} \mathrm{~cm}^{-3}, 2.6 \mu \mathrm{m}\right)$, and kaolin $\left(2.6 \mathrm{~g} \mathrm{~cm}^{-3}, 4.4 \mu \mathrm{m}\right)$ under foodlimited conditions. They observed an increased mortality and slightly decreased reproduction of daphnids for the highest concentration of secondary MPs $\left(10^{5} \mathrm{P} \mathrm{mL}^{-1}\right)$. However, incoherent exposure regimes (different particle sizes, concentrations, and exposure durations, among others) limit a general comparability and conclusion. In fact, the strongest response was driven by the low amount of food (reproduction far below validation criteria, OECD). However, these studies illustrate that (a) adverse effects depend on several factors, e.g., the size and shape of primary vs. secondary MPs, particle concentrations, polymer densities, as 
well as particle interaction with other stressors, and (b) D. magna seems relatively resistant to MP exposures.

The low sensitivity of $D$. magna could be due to its behavioral and morphological adaptations as a generalist filter feeder. D. magna feeds nonselectively on seston components encountering multiple particle sizes, shapes, and materials. High concentrations of SPM reduce the filtration rates as daphnids reject collected particles before ingestion or even narrow their carapace opening to avoid large particles [44, 45]. Besides pre-ingestion adaptations to unsuitable SPM, the peritrophic membrane protects the epithelium of the digestive tract from particleinduced injury. It consists of a complex matrix of chitin microfibrils, polysaccharides, as well as proteins and surrounds the food bolus in the digestive tract of many arthropods [46, 47]. Pores of several nanometers in diameter ensure the transport of digestive fluids and nutrients and protect against pathogens and mechanical damage. The packed food particles pass the digestive tract and are egested with the surrounding peritrophic membrane. Therefore, a direct interaction of MPs with epithelial cells in the digestive tract and thus injuries and a transfer of MPs into the surrounding tissue are unlikely. However, Rosenkranz et al. [48] observed 20 and $1,000 \mathrm{~nm}$ particles in the oil droplets of $D$. magna implying a translocation through the gut's epithelial cells, whereas the majority of studies with nanomaterials did not confirm this observation $[49,50]$.

\subsubsection{Other Crustaceans}

Null effects were found in the amphipod Gammarus pulex exposed to irregular polyethylene terephthalate (PET) fragments $\left(0.4-4,000 \mathrm{P} \mathrm{mL}^{-1}\right.$, size $10-150 \mu \mathrm{m}$; [31]). After 48 days, MPs did not induce any effects on behavior (feeding activity), metabolism (energy reserves), development (molting), and growth. Au et al. [18] tested weathered polypropylene (PP) fibers $\left(20-75 \mu \mathrm{m}, 0-90 \mathrm{P} \mathrm{mL}^{-1}\right)$ as well as laboratory-made PE fragments $\left(10-27 \mu \mathrm{m}, 0-10^{5} \mathrm{P} \mathrm{mL}^{-1}\right)$ in the amphipod Hyalella azteca. In a 10-day acute exposure, PP fibers were more toxic than PE fragments with $\mathrm{LC}_{50}$ values of 71.43 and $46,400 \mathrm{P} \mathrm{mL}^{-1}$, respectively. This might be related to the longer gut retention times of fibers versus fragments and again highlights the importance of particle shape. In the same study, a 42-day chronic exposure to PE fragments significantly decreased growth and reproduction.

At present, besides the studies with D. magna and the amphipods, there is very limited data regarding other freshwater crustaceans as the majority of research focuses on marine species. In addition to the increasing number of laboratory studies, the monitoring of wild populations of the common shrimp Crangon crangon [51] and the Norway lobster Nephrops norvegicus [52] have shown that field populations in marine environments are exposed to MPs. In both studies, MPs (predominantly fibers) were detected in 63\% [51] and 83\% [52] of the examined animals. A recent study by Welden and Cowie [1] with $N$. norvegicus confirmed that MP exposure negatively affects feeding, body mass, metabolic activity, and energy reserves. An 8-month exposure to PP fibers via food $(0.2-5 \mathrm{~mm}$, five fibers 
per feeding) resulted in formations of MP aggregates in the gut of the langoustine that might have reduced the uptake of nutrients. Effects on survival and growth as an outcome of reduced feeding have also been shown in the marine calanoid copepod Calanus helgolandicus [2]. The presence of $20 \mu \mathrm{m}$ PS beads $\left(75 \mathrm{P} \mathrm{mL}^{-1}\right.$ ) reduced the feeding on algae and provoked a feeding preference for smaller algae prey.

Although calanoid copepods are raptorial with strong size and taste discrimination, a study by Lee et al. [53] demonstrated a nonselective ingestion of 0.05, 0.5, and $6 \mu \mathrm{m}$ PS beads by the marine Tigriopus japonicus. While all individuals survived an acute exposure $(96 \mathrm{~h})$, a two-generation chronic exposure to 0.05 $\left(>12.5 \mu \mathrm{g} \mathrm{mL}^{-1}\right)$ and $0.5 \mu \mathrm{m}$ beads $\left(25 \mu \mathrm{g} \mathrm{mL}^{-1}\right)$ induced a concentration- and size-dependent mortality and a significant decrease in fecundity by 0.5 and $6 \mu \mathrm{m}$ PS beads. Again, the observed effects were mainly interpreted as related to an impaired nutritional uptake.

In addition to the presumed nutritional effects, Bundy et al. [54] have shown that calanoid copepods regularly attack, capture, and reject $50 \mu \mathrm{m}$ PS beads. This pre-ingestion behavior may result in a negative energy budget. Additionally, Cole et al. [55] documented that MPs attach to the external carapace and appendages of marine zooplankton, which then might interfere with locomotion, molting, and feeding. The relevance of adhered particles was also shown in the marine crabs Uca rapax and Carcinus maenas $[56,57]$. Here, MP exposure led to an accumulation in the stomach and hepatopancreas but also to an accumulation in the gills. The respiratory uptake and the following adhesion of MPs to the gills might influence the branchial function. For instance, Watts et al. [58] found a significantly decreased oxygen consumption of MP-exposed crabs after $1 \mathrm{~h}$ and observed some adaptation as oxygen consumption returned to normal after $16 \mathrm{~h}$.

\subsubsection{Bivalves}

The transfer of MPs to tissues induces cellular injuries as well as inflammatory responses in the marine filter-feeding mussel $M$. edulis. After 3 days of exposure to 3.0 and $9.6 \mu \mathrm{m}$ PS beads, Browne et al. [24] observed a translocation to the circulatory (hemolymph) system where they remained for up to 48 days. Although the exact pathway is yet unknown, the transfer may be due to specialized enterocytes which in humans and rodents transport MPs from the gut into follicles from which they can translocate into the circulatory system. In addition, particles accumulating in the digestive gland were taken up by cells of the lysosomal system, which resulted in an inflammatory response and histological alterations (lysosomal membrane destabilization) [5]. As a consequence of particle interaction with tissue or hemolymph cells, marine bivalves can express an immediate stress and immune response. This results in an increased production of reactive oxygen species as well as anti-oxidant and glutathione-related enzymes but also changes the hemocyte phagocytosis activity and the ratio of granulocytes and hyalinocytes $[59,60]$. 
Rist et al. [61] exposed the marine Asian green mussel Perna viridis to 1-50 $\mu \mathrm{m}$ polyvinyl chloride (PVC) fragments. MP exposure reduced the filtration and respiration rates, byssus production, as well as motility, while mortality was enhanced. Regarding life-history parameters, MP significantly reduced the reproductive success of Crassostrea gigas and negatively affected larval development of the offspring (PS spheres, 2, $6 \mu \mathrm{m}$ ). Sussarellu et al. [62] linked these effects to a disrupted energy uptake, which resulted in a shift of resources from reproduction to growth. In contrast, studies with $M$. edulis by van Cauwenberghe et al. [63] showed no significant effects of particle exposure to energy reserves (PS spheres, 10, 30, $90 \mu \mathrm{m})$.

Behavioral and physiological responses have also been shown for bivalves exposed to suspended solids. For instance, particle exposure damaged the cilia of the gill filaments in $P$. viridis $(<500 \mu \mathrm{m}$ [64]) and significantly reduced the algal ingestion of $M$. mercenaria (3-40 $\mu \mathrm{m}$, [65]). Therefore, the lack of studies comparing impacts of both MPs and suspended particles hampers a discrimination of MP-associated and more general particle-associated effects.

These studies provide evidence that MP ingestion can affect marine bivalves. As the general feeding strategies are consistent in both marine and freshwater species, the latter may be similarly affected. Still, morphological details of the feedingassociated organs vary in the different bivalve taxa, which can alter feeding-specific characteristics [66].

\subsubsection{Gastropods}

In comparison to bivalves, fewer studies have examined MP toxicity in gastropods, which also have a high capacity to ingest MPs (discussed in Sect. 2.1). The only currently available study on MP toxicity in gastropods suggests limited impacts [36]. In this study, the omnivorous surface grazer $P$. antipodarum was exposed to a mixture of five different polymers (4.6-603 $\mu \mathrm{m}$ particle size; polyamide (PA), polycarbonate (PC), PET, PS, PVC) mixed with food at a ratio of 30 and $70 \%$. After 8 weeks, MPs neither affected the growth (shell width, length, body weight) nor the reproduction (number of produced embryos and ratio of embryos with and without shell). Additionally, MP had no effect on the development of the consecutive generation of juveniles.

\subsubsection{Fish}

Several adverse effects by MP exposures have also been observed for freshwater fishes (Table 2). MPs accumulate in the gills of marine crustaceans, and studies with freshwater fishes demonstrate that this pathway is relevant for vertebrate species too. One example is zebrafish (Danio rerio) in which PS beads accumulate 
in the gills (5 and $20 \mu \mathrm{m})$, gut (5 and $20 \mu \mathrm{m})$, and liver $(5 \mu \mathrm{m})$ [38]. Indeed, histopathological analysis revealed an inflammatory response and accumulation of lipids in the liver as well as oxidative stress. However, these findings were only significant at high concentrations $\left(2 \mathrm{mg} \mathrm{L}^{-1}\right)$ of 0.07 and $5 \mu \mathrm{m}$ beads. In comparison, Karami et al. [37] observed histological alterations in the gills (e.g., basal cell hyperplasia and necrosis in connective tissue) and blood biochemistry parameters (e.g., plasma cholesterol levels, blood HDL levels) of the African catfish (Clarias gariepinus) at lower concentrations of HDPE fragments $\left(50 \mu \mathrm{g} \mathrm{L}{ }^{-1}\right)$. More severe changes (epithelial lifting, hyperplasia, extensive cell sloughing) were reported for higher particle concentration $\left(500 \mu \mathrm{g} \mathrm{L}^{-1}\right)$. Additionally, concentrations of $500 \mu \mathrm{g} \mathrm{L}{ }^{-1}$ significantly affected the degree of tissue change in the liver of exposed individuals. Overall, the authors point toward ethylene monomers (released from HDPE) and internal as well as external abrasions (caused by sharp edges of the fragments) as possible mechanisms for the changes in biomarker responses.

It is well documented that suspended solids can damage organs in several fish species and cause adverse effects similar to those observed for MPs. High concentrations of SPM can accumulate in the gills, disturb the respiratory function, and have been found to translocate into epithelial cells, cause lipid peroxidation, and reduce the tolerance of infection by pathogens $[67,68]$. Additionally, studies with gill epithelial cells (rainbow trout, RTgill-W1) and fluvial fine sediment revealed translocation of fine minerals $\left(<2 \mu \mathrm{m}, 10-250 \mathrm{mg} \mathrm{L}^{-1}\right)$ into the cells as well as material-related cytotoxicity [69]. Here, quartz and feldspar only caused sporadic changes in biomarker response, and exposure to mica (silicate minerals) and kaolin induced cytotoxicity as well as free radicals and cell membrane damage. Therefore, Michel et al. [69] conclude that the uptake of fine particles by gill epithelial cells is a common natural event in aquatic species with the material, size, shape, and concentration determining the impacts.

\subsection{Chemical Impacts}

So far, MPs detected in freshwater environments represent a range of material types (e.g., PE, PS, PET, PVC, PA, and PP), originate from various sources and applications, and represent a plethora of material characteristics. In general, plastic materials are highly functional compounds of synthetic polymers and additives (e.g., plasticizers, flame retardants, colorants). Leachates from diverse plastic products were found to cause chemical toxicity $[70,71]$ induced by monomers, residues of production processes (e.g., catalyzers, stabilizers), and additives. For instance, some leaching components were classified as endocrine disrupting chemicals 
(e.g., phthalates, bisphenol A) adversely affecting life-cycle parameters of a broad range of species [72, 73]. Fries et al. [74] extracted several organic (e.g., phthalates) and inorganic additives (e.g., metals) from MP samples in marine sediments highlighting the relevance of these compounds. Besides additives, adsorbed persistent organic pollutants have been found on MPs (e.g., [75, 76]). The capacity of plastic materials to accumulate hydrophobic organic chemicals is thoroughly studied and frequently applied in passive samplings/monitoring (e.g., [76, 77]). For MPs, the large surface-to-volume ratio supports an accumulation of dissolved pollutants (e.g., PAHs, PBTs, metals), and complex adsorption-desorption patterns have been demonstrated $[77,78]$.

Although a detailed review of the complexity in adsorption-desorption kinetics is beyond the focus of this chapter, the default hypothesis is that MPs readily sorb hydrophobic compounds and therefore act as vectors transferring waterborne contaminants to aquatic organisms (vector hypothesis). However, this idea is controversially discussed. Several laboratory studies illustrate the capacity of MPs to modify adverse effects of chemicals by affecting the bioavailability or acting as an additional stressor. For instance, (1) the exposure to spiked MPs lead to an accumulation of pollutants to the tissues of lugworms (PVC, [6]), mussels (PE and PS, [59]), amphipods (PE, [79]), and fish (LDPE, [39]); (2) Besseling et al. [80] observed a decreased bioaccumulation of polychlorinated biphenyls in lugworms at higher doses of PS particles; (3) Oliveira et al. [40] confirmed a delayed pyreneinduced mortality of juvenile fishes (Pomatoschistus microps) in the presence of PE MPs; and (4) Karami et al. [37] as well as Paul-Pont et al. [60] detected modulations of adverse effects by an exposure to phenanthrene-loaded LDPE fragments (African catfish) and PS beads and fluoranthene (Mytilus spp.), respectively. However, Gouin et al. [81] and Koelmans et al. [82] highlight the minor influence of MPs as vectors for the bioaccumulation of pollutants considering they are outcompeted by natural occurring matter. These authors emphasize the importance of experimental design and chemical analysis in order to understand the relevance and underlying mechanisms of MPs as vectors of bioaccumulative substances. For instance, the introduction of freshly spiked MPs in clean water can result in desorption, which increases dermal exposure [82]. Furthermore, desorbed chemicals might adsorb to food or sediments and decrease the potential relevance of MPs as vectors. In principle, adsorption and desorption patterns follow the partition equilibrium between the available compartments (e.g., biota, food, MPs, sediment, water). This may confound the analysis of single pathways particularly if analytical information is absent (e.g., exposure via ingestion of MPs, food or sediments vs. dermal uptake).

While studies on the vector hypothesis were mostly performed with marine species and persistent organic pollutants, the situation is likely to be very different in freshwater ecosystems. First and foremost, freshwater compartments are exposed to a completely different and much larger spectrum of chemicals than marine systems. This is because they receive a constant input of chemicals from landbased sources (e.g., pesticides) and wastewater (e.g., pharmaceuticals and 
chemicals from personal care products). Many of these compounds are pseudopersistent and biologically highly active but do not occur in marine ecosystems (due to dilution or degradation). Accordingly, freshwater MPs will sorb a completely different set of chemicals than marine ones. In addition, being closer to the source of plastic litter and thus "younger," freshwater MPs might contain higher concentrations of plastic additives. With regard to desorption, physical water properties will affect the transfer of pollutants. The adsorption equilibrium of chemicals to organic materials is highly dependent on water temperature, quantity of organic matter, and the content of inorganic salts [83]. Therefore, the partition equilibrium will be different in salt- and freshwater.

Besides the capacity of MPs to influence the bioavailability of toxic compounds, Besseling et al. [41] suggested that MPs can interfere with intra- and interspecies signaling (e.g., phero- and kairomones) as an integral component of aquatic biocoenosis regulating predator-prey interactions as well as population and community structures [84]. Although they found significant interactions between kairomones and nano-PS when investigating the growth of the water flea D. magna, it remains unclear whether the nano-PS beads increased the bioavailability of kairomones or they observed an additive effect of both stressors [41]. Any disturbance of this interand intraspecies communication can lead to maladaptive responses in both signaler and receiver [85]. So far, it is unclear whether MPs act as info-disruptors as is the case for several metals and pesticides (reviewed in [85]), especially when considering the abundance of additional particulate organic and inorganic matter in aquatic ecosystems.

\subsection{Biofilm-Related Impacts}

Apart from the potential of MPs to act as carriers for chemicals, MPs can serve as substrates for microorganisms. The formation of biofilms [86] can affect the interaction of MPs with biota on multiple levels. For example, the colonization of MPs with microbes and the adsorption of biopolymers increase the nutritional value and improve the "taste" making them more attractive for biota. In contrast, the colonization of MPs with pathogens [87] and toxic algae/bacteria might induce infections/chemical toxicity or avoidance of "bad tasting" MPs. Additionally, biofouling was shown to affect the fate of MPs by changing the particle properties (e.g., density). The formation of biofilms increases the density of floating or buoyant MPs and leads to sedimentation of these low-density particles (reviewed in [88]). Furthermore, in the environment, MPs are most likely incorporated in so-called hetero-aggregates. These aggregates consist of particulate matter (MPs as well as other suspended solids) and microbes (e.g., protozoans, algae) with biopolymers acting as binders. A laboratory study by Lagarde et al. [89] confirmed 
polymer-dependent (PP vs. HDPE) aggregations with the algae Chlamydomonas reinhardtii. While rapid colonization of the surfaces of both HDPE and PP was observed, expanding hetero-aggregates consisting of polymer particles, algae cells, and exopolysaccharides were solely formed by PP. The upscaling of microscopic particles via aggregation can modify their potential for being ingested. While the abundance of microscopic particles and thereby the availability to micro-feeders (e.g., protozoans, planktonic crustaceans) decreases, large hetero-aggregates are accessible to macro-feeders (e.g., planktivorous fishes). Thus, the uptake of one aggregate by macro-feeders might lead to an internal release and exposure to multiple particles of different sizes as digestive fluids digest the biopolymer matrix. However, the sample preparation needed to separate MPs from environmental

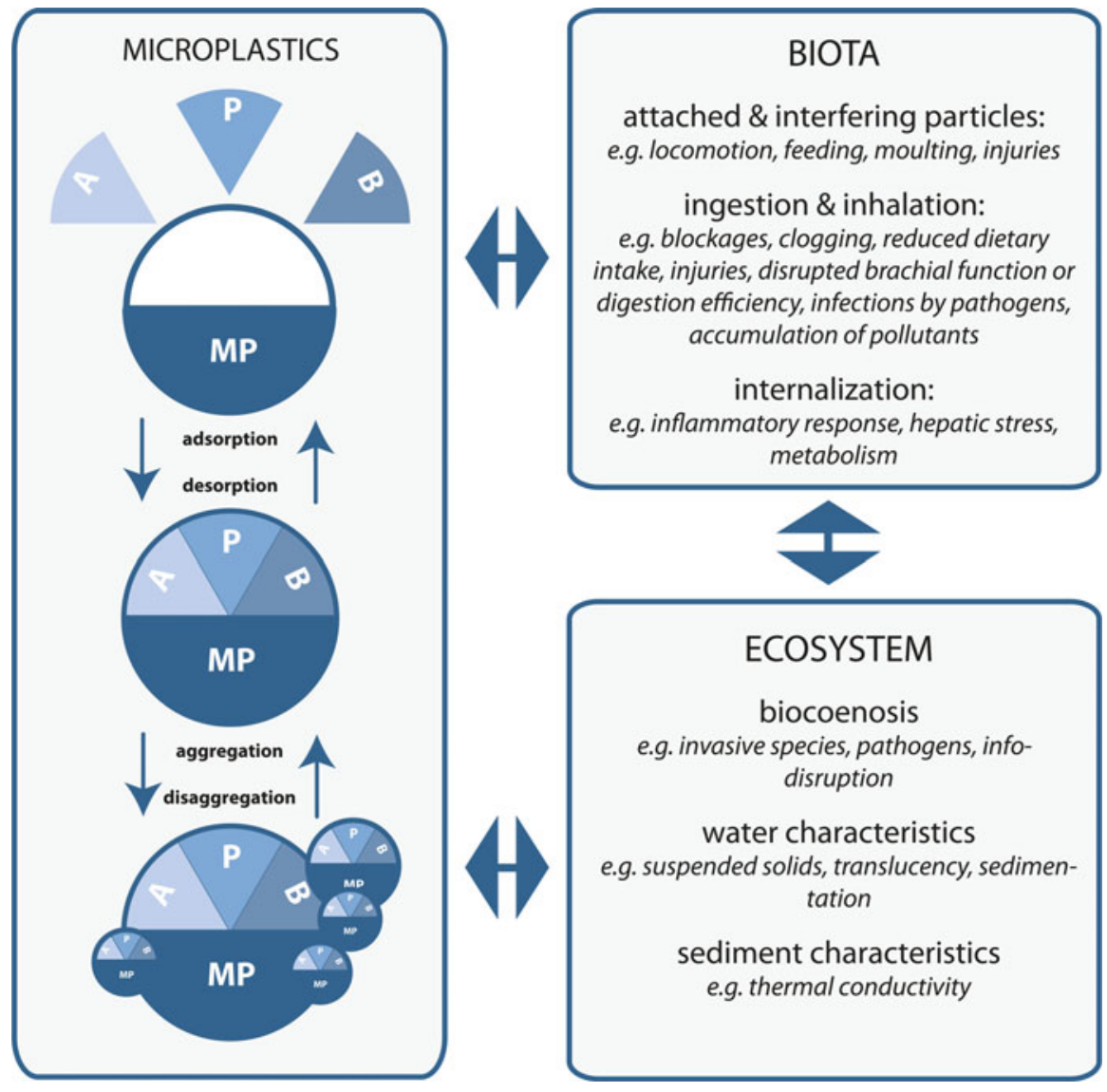

Fig. 2 Schematic overview of interactions between microplastics, biota, and ecosystems. The term microplastics comprises the following interdependent factors: $A$ additives (e.g., polymer monomers, production residues), $P$ pollutants (e.g., HOCs), $B$ biofilm and biopolymers, $M P$ microplastics including varieties of material, density, shape, size, and surface characteristics 
samples destroys hetero-aggregates and makes it almost impossible to investigate them in their natural state.

Overall, MP-associated risks are multifaceted in their nature and the following must be considered: MP-biota interactions, toxicity of polymer-related leachates, adsorption-desorption kinetics of co-occurring compounds, biofilm-related effects, and the formation of hetero-aggregates. Thus, understanding the interaction of all these factors in real-world situations is necessary to evaluate the environmental risk of MP exposures (Fig. 2).

\section{Natural vs. Synthetic Particle Toxicity}

The similarities in the effects caused by exposure to natural fine particles and MPs (see Sect. 3.1) provoke the legitimate question whether MPs have a different toxicological profile compared to natural solids. In general, organisms interact with a variety of particulate matter in freshwater ecosystems and possess adaptations to this potential stressor (e.g., peritrophic membrane, mucus). Species occupying turbid waters might be less sensitive to high concentrations of SPM than species inhabiting clear water. Species-specific effects of exposures to suspended solids were highlighted in numerous studies investigating the anthropogenic introduction of particulate matter (e.g., arising from erosion, dredging; reviewed in $[90,91])$. Suspended particles or fine sediments can reduce feeding rates, decrease reaction distance to prey, influence embryo development, increase mortality, reduce primary production, reduce species diversity, and decrease population size [9094]. Bilotta and Brazier [90] conclude that the magnitude of adverse effects depends on concentration, exposure duration, chemical composition, and particle size distribution. Tolerant species suffered moderately negative effects, while strong effects mainly occurred in intolerant species (see a review on fish in [91]).

These outcomes are also applicable for the effect studies with MPs and, thus, illustrate the importance of benchmarking the toxicity of MPs in comparison to naturally occurring particles. Considering the available literature, we can hypothesize a higher particle toxicity of MPs since adverse effects were observed at lower concentrations compared to fine sediments. However, studies with suspended solids have used a variety of units (particle per volume, mass per volume, parts per million), size classes, densities, and experimental conditions, which impedes a direct comparison. Accordingly, to answer the question whether the particle toxicity of MPs is indeed different from natural materials, ecotoxicological studies need to include reference treatments with natural particles (e.g., minerals, charcoal). However, investigating particle toxicity necessitates a highly complex approach featuring multiple factors, e.g., concentration, material, size, shape, density, and surface characteristics. 
In principle, aquatic species interact with MPs through a variety of pathways featuring direct or indirect ingestion, respiration, or attachment to the body surface. Therefore, a single stressor (e.g., inert particle) influences life-cycle parameters on multiple levels. For instance, the presence of MPs can limit the nutrient assimilation by reducing the proportion of available food particles or by interfering with feeding mechanisms and locomotion, influencing digestion efficiency, and driving behavioral adaptations (e.g., avoidance, foraging). This implies that effect studies with MPs should focus on multiple endpoints including typical life-cycle parameters (e.g., reproduction, growth, nutritional state), histological analyses, and biomarker responses. Furthermore, the implementation of time-course, chronic, and multigenerational test designs might help uncover adaptive responses as well as cascading effects in populations. Only the simultaneous investigation and direct comparison of the toxicity of natural and polymeric particles will enable discovering specific MP-associated risks in the diversity of particulate matter. In the absence of this reference, adverse effects of MPs observed in the laboratory could be nothing but a representation of the (normal) biological response and physiological condition induced by natural particles. However, species in freshwater systems are adapted to naturally occurring particles, and it remains relatively unclear whether polymer particles act differently or have the potential to bypass protective adaptations.

\section{Implications for Freshwater Ecosystems}

Although plastics have been released into the environment for many years, researchers have barely begun to understand the extent of MP distribution in freshwater systems. As such, the environmental impacts of MPs have not been thoroughly evaluated. Importantly, the term "microplastics" encompasses a tremendous variety of polymers that in turn spans a very wide range of sizes, shapes, and chemical compositions. In this sense, MPs do not represent one stressor, whose impacts can be evaluated relatively easily, but a very large number of stressors that potentially act jointly. The use of copolymers, product-specific mixtures of additives, and source- and pathway-specific sorbed pollutants further complicates the situation.

In physical terms, MPs can influence water (e.g., translucency [42]), sedimentation (e.g., feces [95]), and sediment (e.g., thermal conductivity [96]) characteristics. In ecological terms, MPs can affect the aquatic biocoenosis on a large scale (Fig. 2), for instance, as vectors for invasive species and pathogens [97-99]. The existing toxicological studies mostly focus on the interaction of MPs and biota in simplified exposure regimes, commonly using spherical microbeads composed of a single polymer. Here, there is a tendency for elevated adverse effects (e.g., reduced reproduction, inflammatory response) with decreasing particle sizes. At the current 
state of research, MP toxicity has been studied and in some cases demonstrated at relatively high concentrations. This has been criticized as lacking ecological relevance. However, the environmental concentrations of very small, biologically relevant MPs $(<100 \mu \mathrm{m})$ remain unknown but may be higher than predicted based on analyzing larger MPs. In addition, species-specific responses may be incorrectly estimated by using microspheres alone. The use of multiple polymer types, shapes, and sizes may establish that some species are more sensitive than originally predicted.

It is already established that high concentrations of suspended solids affect community structure through changes in growth, reproduction, and species interactions. Accordingly, evolutionary adaptations (e.g., peritrophic membrane, mucus, avoidance) might explain the species-dependent resistance to high concentrations of MPs (e.g., D. magna, G. pulex). However, MPs can infiltrate habitats normally low in suspended solid and thereby affect more sensitive species.

The continuing release of MPs through the breakdown of littered plastics that are already present in the environment means that MPs may become an increasingly important freshwater pollutant in the future. In addition, the high demand of plastic materials/products will not decrease if continuing the business-as-usual mode. Accordingly, without rethinking and restructuring our resource production and use (e.g., within the framework of a circular economy, [100]), plastic waste will further accumulate in the biosphere.

Overall, traditional approaches for toxicity testing may not be appropriate for a multifaceted stressor such as MPs. The default assumption that standard model organisms act as appropriate surrogates for aquatic biocoenoses may ignore species-specific responses of more sensitive species. In addition, consideration of future scenarios may render vector-related impacts (e.g., biofilms, transfer of additives, and hydrophobic persistent pollutant) more prominent.

Our knowledge regarding the impacts of MPs on freshwater species is limited at the present time, although we are beginning to appreciate some of the complexities as more laboratory and field data becomes available. First and foremost, we need to prioritize which physical and chemical MP characteristics are toxicologically and ecologically most important. In this context, there is also a lot to learn from other disciplines with important data already abundant (e.g., ecological feeding studies, suspended solids, medicine, nanomaterials; see e.g., chapter "Freshwater Microplastics: Challenges for Regulation and Management"). Ecological knowledge regarding the adaptations of specific species as well as factors driving species compositions might help to identify especially sensitive biota. In addition, understanding the role of MPs relative to other stressors will require a multidisciplinary approach. Overall, understanding the complex interactions of plastics and the environment can only be achieved by a joint effort. The upcoming challenge will be to unravel the role that MPs play in a multiple-particle world. 


\section{References}

1. Welden NAC, Cowie PR (2016) Environment and gut morphology influence microplastic retention in langoustine, Nephrops norvegicus. Environ Pollut 214:859-865. doi:10.1016/j.envpol. 2016.03.067

2. Cole M, Lindeque P, Fileman E et al (2015) The impact of polystyrene microplastics on feeding, function and fecundity in the marine copepod Calanus helgolandicus. Environ Sci Technol 49:1130-1137. doi:10.1021/es504525u

3. Phuong NN, Zalouk-Vergnoux A, Poirier L et al (2016) Is there any consistency between the microplastics found in the field and those used in laboratory experiments? Environ Pollut 211:111-123. doi:10.1016/j.envpol.2015.12.035

4. Wright SL, Thompson RC, Galloway TS (2013) The physical impacts of microplastics on marine organisms: a review. Environ Pollut 178:483-492. doi:10.1016/j.envpol.2013.02.031

5. von Moos N, Burkhardt-Holm P, Koehler A (2012) Uptake and effects of microplastics on cells and tissue of the Blue mussel Mytilus edulis L. after an experimental exposure. Environ Sci Technol 46:327-335. doi:10.1021/es302332w

6. Browne MA, Niven SJ, Galloway TS et al (2013) Microplastic moves pollutants and additives to worms, reducing functions linked to health and biodiversity. Curr Biol 23:2388-2392. doi:10.1016/j.cub.2013.10.012

7. Cummins KW, Klug MJ (1979) Feeding ecology of stream invertebrates. Annu Rev Ecol Syst 10:147-172. doi:10.1146/annurev.es.10.110179.001051

8. Burns CW (1968) The relationship between body size of filter-feeding Cladocera and the maximum size of particle ingested. Limnol Oceanogr 13:675-678. doi:10.4319/lo.1968.13.4. 0675

9. Sanders RW, Porter KG, Bennett SJ, Debiase AE (1989) Seasonal patterns of bacterivory by flagellates, ciliates, rotifers, and cladocerans in a freshwater planktonic community. Limnol Oceanogr 34:673-687. doi:10.4319/lo.1989.34.4.0673

10. Thouvenot A, Richardot M, Debroas D, Devaux J (1999) Bacterivory of metazooplankton, ciliates and flagellates in a newly flooded reservoir. J Plankton Res 21:1659-1679. doi:10. 1093/plankt/21.9.1659

11. Børsheim KY (1984) Clearance rates of bacteria-sized particles by freshwater ciliates, measured with monodisperse fluorescent latex beads. Oecologia 63:286-288. doi:10.1007/ BF00379891

12. Agasild H, Nõges T (2005) Cladoceran and rotifer grazing on bacteria and phytoplankton in two shallow eutrophic lakes: in situ measurement with fluorescent microspheres. J Plankton Res 27:1155-1174. doi:10.1093/plankt/fbi080

13. Ooms-Wilms AL, Postema G, Gulati RD (1995) Evaluation of bacterivory of Rotifera based on measurements of in situ ingestion of fluorescent particles, including some comparisons with Cladocera. J Plankton Res 17:1057-1077. doi:10.1093/plankt/17.5.1057

14. DeMott WR (1986) The role of taste in food selection by freshwater zooplankton. Oecologia 69:334-340. doi:10.1007/BF00377053

15. Bern L (1990) Size-related discrimination of nutritive and inert particles by freshwater zooplankton. J Plankton Res 12:1059-1067. doi:10.1093/plankt/12.5.1059

16. Scherer C, Brennholt N, Reifferscheid G, Wagner M (2017) Feeding strategy and development drive the ingestion of microplastics by freshwater invertebrates, in preparation

17. Imhof HK, Ivleva NP, Schmid J et al (2013) Contamination of beach sediments of a subalpine lake with microplastic particles. Curr Biol 23:1-15. doi:10.1016/j.cub.2013.09.001

18. Au SY, Bruce TF, Bridges WC, Klaine SJ (2015) Responses of Hyalella azteca to acute and chronic microplastic exposures. Environ Toxicol Chem 34:2564-2572. doi:10.1002/etc.3093

19. Dantas DV, Barletta M, da Costa MF (2012) The seasonal and spatial patterns of ingestion of polyfilament nylon fragments by estuarine drums (Sciaenidae). Environ Sci Pollut Res 19: 600-606. doi:10.1007/s11356-011-0579-0 
20. Possatto FE, Barletta M, Costa MF et al (2011) Plastic debris ingestion by marine catfish: an unexpected fisheries impact. Mar Pollut Bull 62:1098-1102. doi:10.1016/j.marpolbul.2011. 01.036

21. Ramos JAA, Barletta M, Costa MF (2012) Ingestion of nylon threads by gerreidae while using a tropical estuary as foraging grounds. Aquat Biol 17:29-34. https://doi.org/10.3354/ ab00461

22. Drenner RW, Mummert JR, Denoyelles F, Kettle D (1984) Selective particle ingestion by a filter-feeding fish and its impact on phytoplankton community structure. Limnol Oceanogr 29:941-948. doi:10.4319/lo.1984.29.5.0941

23. Jeong C-B, Won E-J, Kang H-M et al (2016) Microplastic size-dependent toxicity, oxidative stress induction, and p-JNK and p-P38 activation in the monogonont rotifer (Brachionus koreanus). Environ Sci Technol 50:8849-8857. doi:10.1021/acs.est.6b01441

24. Browne MA, Dissanayake A, Galloway TS et al (2008) Ingested microscopic plastic translocates to the circulatory system of the mussel, Mytilus edulis (L.) Environ Sci Technol 42: 5026-5031. doi:10.1021/es800249a

25. Wootton RJ (1989) Ecology of teleost fishes. Springer, Dordrecht. doi:10.1007/978-94-0090829-1

26. Gerking SD (1994) Feeding ecology of fish. Academic Press, San Diego

27. Fenchel T (1980) Suspension feeding in ciliated protozoa: feeding rates and their ecological significance. Microb Ecol 6:13-25. doi:10.2307/4250595

28. Geller W, Müller H (1981) The filtration apparatus of cladocerans: filter mesh-size and their implications on food selectivity. Oecologia 2:316-321

29. Bleiwas AH, Stokes PM (1985) Collection of large and small food particles by Bosmina. Limnol Oceanogr 30:1090-1092. doi:10.4319/lo.1985.30.5.1090

30. Price HJ (1988) Feeding mechanisms in marine and freshwater zooplankton. Bull Mar Sci 43: 327-343

31. Weber A, Scherer C, Brennholt N et al (2017) Microplastics do not negatively affect the freshwater invertebrate Gammarus pulex, in preparation

32. Sherr BF, Sherr EB, Fallon RD (1987) Use of monodispersed, fluorescently labeled bacteria to estimate in situ protozoan bacterivory. Appl Environ Microbiol 53:958-965. doi:10.1016/ 0198-0254(87)90950-2

33. DeMott WR (1988) Discrimination between algae and artificial particles by freshwater and marine copepods. Limnol Oceanogr 33:397-408. doi:10.4319/lo.1988.33.3.0397

34. Rehse S, Kloas W, Zarfl C (2016) Short-term exposure with high concentrations of pristine microplastic particles leads to immobilisation of Daphnia magna. Chemosphere 153: 91-99. doi:10.1016/j.chemosphere.2016.02.133

35. Ogonowski M, Schür C, Jarsén Å, Gorokhova E (2016) The effects of natural and anthropogenic microparticles on individual fitness in Daphnia magna. PLoS One 11:e0155063. doi:10.1371/journal.pone. 0155063

36. Imhof HK, Laforsch C (2016) Hazardous or not - are adult and juvenile individuals of Potamopyrgus antipodarum affected by non-buoyant microplastic particles? Environ Pollut 218:383-391. doi:10.1016/j.envpol.2016.07.017

37. Karami A, Romano N, Galloway T, Hamzah H (2016) Virgin microplastics cause toxicity and modulate the impacts of phenanthrene on biomarker responses in African catfish (Clarias gariepinus). Environ Res 151:58-70. doi:10.1016/j.envres.2016.07.024

38. Lu Y, Zhang Y, Deng Y et al (2016) Uptake and accumulation of polystyrene microplastics in zebra fish (Danio rerio) and toxic effects in liver. Environ Sci Technol 50:4054-4060. https://doi.org/10.1021/acs.est.6b00183

39. Rochman CM, Hoh E, Kurobe T, Teh SJ (2013) Ingested plastic transfers hazardous chemicals to fish and induces hepatic stress. Sci Rep 3:3263. doi:10.1038/srep03263 
40. Oliveira M, Ribeiro A, Hylland K, Guilhermino L (2013) Single and combined effects of microplastics and pyrene on juveniles (0+ group) of the common goby Pomatoschistus microps (Teleostei, Gobiidae). Ecol Indic 34:641-647. doi:10.1016/j.ecolind.2013.06.019

41. Besseling E, Wang B, Lurling M, Koelmans AA (2014) Nanoplastic affects growth of S. obliquus and reproduction of D. magna. Environ Sci Technol 48:12336-12343. doi:10. 1021/es503001d

42. Sjollema SB, Redondo-Hasselerharm P, Leslie HA et al (2016) Do plastic particles affect microalgal photosynthesis and growth? Aquat Toxicol 170:259-261. doi:10.1016/j.aquatox. 2015.12.002

43. Zhang C, Chen X, Wang J, Tan L (2017) Toxic effects of microplastic on marine microalgae Skeletonema costatum: interactions between microplastic and algae. Environ Pollut 220: 1282-1288. doi:10.1016/j.envpol.2016.11.005

44. Gliwicz ZM, Siedlar E (1980) Food size limitation and algae interfering with food collection in Daphnia. Arch Hydrobiol 88:155-177

45. Kirk KL (1991) Inorganic particles alter competition in grazing plankton: the role of selective feeding. Ecology 72:915-923. doi:10.2307/1940593

46. Peters W (1968) Occurrence, composition and fine structure of peritrophic membranes in animals. Z Morphol Tiere 62:9-57. doi:10.1007/BF00401488

47. Georgi O (1969) Fine structure of peritrophic membranes in Crustacea. Z Morphol Tiere 65: 225-273

48. Rosenkranz P, Chaudhry Q, Stone V, Fernandes TF (2009) A comparison of nanoparticle and fine particle uptake by Daphnia magna. Environ Toxicol Chem 28:2142-2149

49. Tervonen K, Waissi G, Petersen EJ et al (2010) Analysis of fullerene-c60 and kinetic measurements for its accumulation and depuration in Daphnia magna. Environ Toxicol Chem 29: 1072-1078. doi:10.1002/etc. 124

50. Khan FR, Kennaway GM, Croteau M-N et al (2014) In vivo retention of ingested Au NPs by Daphnia magna: no evidence for trans-epithelial alimentary uptake. Chemosphere 100: 97-104. doi:10.1016/j.chemosphere.2013.12.051

51. Devriese LI, van der Meulen MD, Maes T et al (2015) Microplastic contamination in brown shrimp (Crangon crangon, Linnaeus 1758) from coastal waters of the Southern North Sea and Channel area. Mar Pollut Bull 98:179-187. doi:10.1016/j.marpolbul.2015.06.051

52. Murray F, Cowie PR (2011) Plastic contamination in the decapod crustacean Nephrops norvegicus (Linnaeus, 1758). Mar Pollut Bull 62:1207-1217. doi:10.1016/j.marpolbul.2011.03. 032

53. Lee K, Shim WJ, Kwon OY, Kang J (2013) Size-dependent effects of micro polystyrene particles in the marine copepod Tigriopus japonicus. Environ Sci Technol 47:11278-11283. doi: $10.1021 /$ es401932b

54. Bundy MH, Gross TF, Vanderploeg HA, Strickler JR (1998) Perception of inert particles by calanoid copepods: behavioral observations and a numerical model. J Plankton Res 20: 2129-2152. doi:10.1093/plankt/20.11.2129

55. Cole M, Lindeque P, Fileman E et al (2013) Microplastic ingestion by zooplankton. Environ Sci Technol 47:6646-6655. doi:10.1021/es400663f

56. Brennecke D, Ferreira EC, Costa TMM et al (2014) Ingested microplastics $(<100 \mu \mathrm{m})$ are translocated to organs of the tropical fiddler crab Uca rapax. Mar Pollut Bull 96:491-495. doi:10.1016/j.marpolbul.2015.05.001

57. Watts AJR, Lewis C, Goodhead RM et al (2014) Uptake and retention of microplastics by the shore crab Carcinus maenas. Environ Sci Technol 48:8823-8830. doi:10.1021/es501090e

58. Watts AJR, Urbina MA, Goodhead RM et al (2016) Effect of microplastic on the gills of the shore crab Carcinus maenas. Environ Sci Technol 50:5364-5369. doi:10.1021/acs.est. $6 \mathrm{~b} 01187$ 
59. Avio CG, Gorbi S, Milan M et al (2015) Pollutants bioavailability and toxicological risk from microplastics to marine mussels. Environ Pollut 198:211-222. doi:10.1016/j.envpol.2014.12. 021

60. Paul-Pont I, Lacroix C, González Fernández C et al (2016) Exposure of marine mussels Mytilus spp. to polystyrene microplastics: toxicity and influence on fluoranthene bioaccumulation. Environ Pollut 216:724-737. doi:10.1016/j.envpol.2016.06.039

61. Rist SE, Assidqi K, Zamani NP et al (2016) Suspended micro-sized $\{P V C\}$ particles impair the performance and decrease survival in the Asian green mussel Perna viridis. Mar Pollut Bull 111:213-220. doi:10.1016/j.marpolbul.2016.07.006

62. Sussarellu R, Suquet M, Thomas Y et al (2016) Oyster reproduction is affected by exposure to polystyrene microplastics. Proc Natl Acad Sci 113:2430-2435. doi:10.1073/pnas. 1519019113

63. Van Cauwenberghe L, Claessens M, Vandegehuchte MB, Janssen CR (2015) Microplastics are taken up by mussels (Mytilus edulis) and lugworms (Arenicola marina) living in natural habitats. Environ Pollut 199:10-17. doi:10.1016/j.envpol.2015.01.008

64. Cheung SG, Shin PKS (2005) Size effects of suspended particles on gill damage in greenlipped mussel Perna viridis. Mar Pollut Bull 51:801-810

65. Bricelj VM, Malouf RE (1984) Influence of algal and suspended sediment concentrations on the feeding physiology of the hard clam Mercenaria mercenaria. Mar Biol 84:155-165. doi:10.1007/BF00393000

66. Dillon RTJ (2000) The ecology of freshwater molluscs. Cambridge University Press, Cambridge, p 499. doi:10.1017/CBO9781107415324.004

67. Redding JM, Schreck CB, Everest FH (1987) Physiological effects on coho salmon and steelhead of exposure to suspended solids. Trans Am Fish Soc 116:737-744. doi:10.1577/ 1548-8659(1987)116<737:PEOCSA $>2.0$. CO;2

68. Michel C, Schmidt-Posthaus H, Burkhardt-Holm P, Richardson J (2013) Suspended sediment pulse effects in rainbow trout (Oncorhynchus mykiss) - relating apical and systemic responses. Can J Fish Aquat Sci 70:630-641. doi:10.1139/cjfas-2012-0376

69. Michel C, Herzog S, De Capitani C et al (2014) Natural mineral particles are cytotoxic to rainbow trout gill epithelial cells in vitro. PLoS One 9:e100856. doi:10.1371/journal.pone. 0100856

70. Lithner D, Larsson A, Dave G (2011) Environmental and health hazard ranking and assessment of plastic polymers based on chemical composition. Sci Total Environ 409:3309-3324. doi:10.1016/j.scitotenv.2011.04.038

71. Lithner D, Damberg J, Dave G, Larsson $\AA$ (2009) Leachates from plastic consumer products Screening for toxicity with Daphnia magna. Chemosphere 74:1195-1200. doi:10.1016/j. chemosphere.2008.11.022

72. Oehlmann J, Schulte-Oehlmann U, Kloas W et al (2009) A critical analysis of the biological impacts of plasticizers on wildlife. Philos Trans R Soc Lond Ser B Biol Sci 364:2047-2026

73. Lambert S, Sinclair C, Boxall A (2014) Occurrence, degradation, and effect of polymer-based materials in the environment. Rev Environ Contam Toxicol 227:1-53

74. Fries E, Dekiff JH, Willmeyer J et al (2013) Identification of polymer types and additives in marine microplastic particles using pyrolysis-GC/MS and scanning electron microscopy. Environ Sci: Processes Impacts 15:1949-1956. doi:10.1039/c3em00214d

75. Antunes JC, Frias JGL, Micaelo AC, Sobral P (2013) Resin pellets from beaches of the Portuguese coast and adsorbed persistent organic pollutants. Estuar Coast Shelf Sci 130: 62-69. doi:10.1016/j.ecss.2013.06.016

76. Mizukawa K, Takada H, Ito M et al (2013) Monitoring of a wide range of organic micropollutants on the Portuguese coast using plastic resin pellets. Mar Pollut Bull 70: 296-302. doi:10.1016/j.marpolbul.2013.02.008 
77. Bakir A, Rowland SJ, Thompson RC (2012) Competitive sorption of persistent organic pollutants onto microplastics in the marine environment. Mar Pollut Bull 64:2782-2789. doi:10. 1016/j.marpolbul.2012.09.010

78. Bakir A, Rowland SJ, Thompson RC (2014) Enhanced desorption of persistent organic pollutants from microplastics under simulated physiological conditions. Environ Pollut 185: 16-23. doi:10.1016/j.envpol.2013.10.007

79. Chua EM, Shimeta J, Nugegoda D et al (2014) Assimilation of polybrominated diphenyl ethers from microplastics by the marine amphipod, Allorchestes compressa. Environ Sci Technol 48:8127-8134. https://doi.org/10.1021/es405717z

80. Besseling E, Wegner A, Foekema EM et al (2013) Effects of microplastic on fitness and PCB bioaccumulation by the lugworm Arenicola marina (L.) Environ Sci Technol 47:593-600. doi:10.1021/es302763x

81. Gouin T, Roche N, Lohmann R, Hodges G (2011) A thermodynamic approach for assessing the environmental exposure of chemicals absorbed to microplastic. Environ Sci Technol 45: 1466-1472. doi:10.1021/es1032025

82. Koelmans AA, Bakir A, Burton GA, Janssen CR (2016) Microplastic as a vector for chemicals in the aquatic environment: critical review and model-supported reinterpretation of empirical studies. Environ Sci Technol 50:3315-3326. doi:10.1021/acs.est.5b06069

83. Endo S, Koelmans AA (2010) Sorption of hydrophobic organic compounds to plastics in the marine environment: equilibrium. In: The handbook of environmental chemistry. Springer, Berlin, pp 41-53

84. Pohnert G, Steinke M, Tollrian R (2007) Chemical cues, defence metabolites and the shaping of pelagic interspecific interactions. Trends Ecol Evol 22:198-204. doi:10.1016/j.tree.2007.01.005

85. Lürling M, Scheffer M (2007) Info-disruption: pollution and the transfer of chemical information between organisms. Trends Ecol Evol 22:374-379. doi:10.1016/j.tree.2007.04.002

86. Harrison JP, Hoellein TJ, Sapp M, Tagg AS, Ju-Nam Y, Ojeda JJ (2017) Microplasticassociated biofilms: a comparison of freshwater and marine environments. In: Wagner M, Lambert $\mathrm{S}$ (eds) Freshwater microplastics: emerging environmental contaminants? Springer, Heidelberg. doi:10.1007/978-3-319-61615-5_9 (in this volume)

87. Kirstein IV, Kirmizi S, Wichels A et al (2016) Dangerous hitchhikers? Evidence for potentially pathogenic Vibrio spp. on microplastic particles. Mar Environ Res 120:1-8. doi:10. 1016/j.marenvres.2016.07.004

88. Oberbeckmann S, Löder MGJ, Labrenz M (2015) Marine microplastic-associated biofilms a review. Environ Chem 12:551-562. doi:10.1071/EN15069

89. Lagarde F, Olivier O, Zanella M et al (2016) Microplastic interactions with freshwater microalgae: hetero-aggregation and changes in plastic density appear strongly dependent on polymer type. Environ Pollut 215:331-339. doi:10.1016/j.envpol.2016.05.006

90. Bilotta GS, Brazier RE (2008) Understanding the influence of suspended solids on water quality and aquatic biota. Water Res 42:2849-2861. doi:10.1016/j.watres.2008.03.018

91. Chapman JM, Proulx CL, Veilleux MAN et al (2014) Clear as mud: a meta-analysis on the effects of sedimentation on freshwater fish and the effectiveness of sediment-control measures. Water Res 56:190-202. doi:10.1016/j.watres.2014.02.047

92. Cordone A, Kelley D (1961) The influence of inorganic sediment on the aquatic life of streams. Calif Fish Game 47:189-228

93. Newcombe CP, MacDonald D (1991) Effects of suspended sediments on aquatic ecosystems. North Am J Fish Manag 11:72-82. doi:10.1577/1548-8675(1991)011<0072

94. Kjelland ME, Woodley CM, Swannack TM, Smith DL (2015) A review of the potential effects of suspended sediment on fishes: potential dredging-related physiological, behavioral, and 
transgenerational implications. Environ Syst Decis 35:334-350. doi:10.1007/s10669-0159557-2

95. Cole M, Lindeque PK, Fileman E et al (2016) Microplastics alter the properties and sinking rates of zooplankton faecal pellets. Environ Sci Technol 50:3239-3246. doi:10. 1021/acs.est.5b05905

96. Carson HS, Colbert SL, Kaylor MJ, McDermid KJ (2011) Small plastic debris changes water movement and heat transfer through beach sediments. Mar Pollut Bull 62: 1708-1713. doi:10.1016/j.marpolbul.2011.05.032

97. Zettler ER, Mincer TJ, Amaral-Zettler LA (2013) Life in the "plastisphere": microbial communities on plastic marine debris. Environ Sci Technol 47:7137-7146. doi:10.1021/ es401288x

98. Goldstein MC, Rosenberg M, Cheng L (2012) Increased oceanic microplastic debris enhances oviposition in an endemic pelagic insect. Biol Lett 8:817-820. doi:10.1098/rsbl. 2012.0298

99. Barnes DKA, Milner P (2005) Drifting plastic and its consequences for sessile organism dispersal in the Atlantic Ocean. Mar Biol 146:815-825. doi:10.1007/s00227-004-1474-8

100. Eriksen M, Thiel M, Prindiville M, Kiessling T (2017) Microplastic: what are the solutions?. In: Wagner M, Lambert S (eds) Freshwater microplastics: emerging environmental contaminants? Springer, Heidelberg. doi:10.1007/978-3-319-61615-5_13 (in this volume)

101. Lohmann R, Booij K, Smedes F, Vrana B (2012) Use of passive sampling devices for monitoring and compliance checking of POP concentrations in water. Environ Sci Pollut Res 19: 1885-1895. doi:10.1007/s11356-012-0748-9

Open Access This chapter is licensed under the terms of the Creative Commons Attribution 4.0 International License (http://creativecommons.org/licenses/by/4.0/), which permits use, sharing, adaptation, distribution and reproduction in any medium or format, as long as you give appropriate credit to the original author(s) and the source, provide a link to the Creative Commons license and indicate if changes were made.

The images or other third party material in this chapter are included in the chapter's Creative Commons license, unless indicated otherwise in a credit line to the material. If material is not included in the chapter's Creative Commons license and your intended use is not permitted by statutory regulation or exceeds the permitted use, you will need to obtain permission directly from the copyright holder.

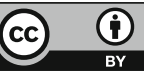

